\title{
Tereza Trautman e Os homens que eu tive: uma história sobre cinema e censura
}

////////////////// $:$ Ana Maria Veiga ${ }^{1}$

1. Professora substituta do Departamento de História da Universidade Federal de Santa Catarina. Doutora em História Cultural com a tese Cineastas brasileiras em tempos de ditadura: cruzamentos, fugas, especificidades (UFSC, 2013). Tem experiência profissional em realização audiovisual. E-mail: amveiga@yahoo.com.br 
Resumo

Além da política, a censura moral foi amplamente praticada no Brasil, visando filmes não adequados aos padrões vigentes durante o regime militar. No contexto do cinema erótico, incentivado pela Embrafilme, uma jovem cineasta viu seus sonhos naufragarem em 1973 com um ato da censura. Este artigo analisa a interdição do filme Os homens que eu tive, de Tereza Trautman, como elemento representativo da arbitrariedade com base na moral e nos bons costumes, fortemente valorizados a partir do golpe militar.

\section{Palavras-chave}

Tereza Trautman, Os homens que eu tive, cinema, história, censura.

Abstract

Beyond politics, the moral censorship was widely practiced in Brazil toward films that contested the military patterns of conduct. In the context of erotic cinema, promoted by Embrafilme, a young director saw her dreams sink in 1973 with a censorship act. This article analyses the interdiction of the film Os homens que eu tive [the men that I've had], by Tereza Trautman, as a representative element of arbitrariness with its basis on moral and good habits, strongly emphasized from the military coup d'état.

Keywords

Tereza Trautman, Os homens que eu tive, cinema, history, censorship. 
Enquanto grande parte do mundo ocidental vivia a plena transformação social, cultural e política, impulsionada pelas manifestações ocorridas principalmente no ano de 1968 e a entrada em cena do Movimento de Liberação da Mulher e do movimento feminista, no Brasil tal efervescência esbarrava em alguns obstáculos nos primeiros anos da década de 1970. A ditadura militar, recrudescida a partir do Ato Institucional número 5 (promulgado em dezembro de 1968), ainda impunha sobre a sociedade rédeas mais do que puxadas. Era um momento de intensa censura e opressão. Entre os denominados subversivos estavam principalmente estudantes, artistas e intelectuais de esquerda, inconformados com o regime autoritário de um governo que abafava e reprimia manifestações que lhe fossem contrárias. Muitos foram perseguidos, presos ou exilados, diante do lema central da ditadura: "Brasil: ame-o ou deixe-o", em que amar o país significava estar de acordo ou resignado à mão militar do poder.

Podemos afirmar que a censura aos meios de comunicação, reconhecendo sua importância ideológica, funcionou como um aparato paralelo de repressão, montado para cortar aquilo que não encontrasse a convergência com o projeto militar para a nação brasileira. Reportagens, músicas, filmes e até obras de arte, tudo passava por uma edição ideológica, o que muitas vezes gerava um resultado totalmente diferente do que era proposto na autoria. Por outro lado, a licença poética, a alegoria e a ficção permitiam certo espaço de manobra política no campo das artes. 
Em meio a esse contexto, a cena cinematográfica brasileira ganhou contornos curiosos na década de 1970. Com a criação da Embrafilme, em 1969, o governo começou a investir na indústria cinematográfica brasileira e passou a exigir que as salas de cinema exibissem também filmes nacionais. Muitos diretores críticos ao regime estavam afastados de suas atividades, alguns do próprio país, enquanto outros viriam a assumir papeis administrativos junto à Embrafilme (MALAFAIA, 2007, p. 336). Os filmes a serem exibidos nos cinemas não poderiam de modo algum questionar o regime. Entre alguns poucos que ainda tentavam fazê-lo, a década de 1970 viu explodir nas telas um gênero cinematográfico brasileiro que ficou conhecido como pornochanchada, que misturava humor e erotismo em seus roteiros água com açúcar, inspirados nas chanchadas das décadas anteriores, como pano de fundo para cenas picantes. Wolney Malafaia resume a situação:

A década de 1970, principalmente na sua segunda metade, representará uma fase em que a política oficial de cultura na área cinematográfica, levada à frente pela Embrafilme, colherá seus melhores resultados. [...] De qualquer forma, mesmo diante de todo esse sucesso, produções como Dona Flor e seus dois maridos ou Xica da Silva serão exceções num universo inundado por jecas, trapalhões e pornochanchadas (MALAFAIA, 2007, p. 345).

2. Giordano informa ainda que, a partir do governo Médici, pornografia e erotismo também entravam na esfera da Segurança Nacional.
O prefixo pornô não tem a correspondência explícita dos dias de hoje, mas os corpos das mulheres eram fartamente exibidos, seguindo a fragmentação orientada pela censura: um seio de cada vez ${ }^{2}$ (GIORDANO, 2010). As atrizes desses filmes eram automaticamente classificadas como prostitutas, pois estavam ali como duplo objeto de satisfação masculina: para os homens com quem se relacionavam nas películas e para o público espectador, nas salas de cinema.

Nuno Cesar Abreu (1996) traça um panorama detalhado desse gênero tipicamente brasileiro nos anos 1970, apontando para uma tendência no campo cinematográfico que acabou conquistando um grande filão de mercado. O autor vê a pornochanchada como uma 
expressão da onda de liberação dos costumes da época (ABREU, 1996, p. 74-75). Isso se dá em um contexto ambivalente das relações entre cinema e Estado em tempos de autoritarismo. Com cenas consideradas vulgares e apelativas, esse conjunto de filmes seria "fruto de um momento de forte repressão do poder à produção cultural"; a pornochanchada, para Abreu, era uma "filha da ditadura", tendo sido inaugurada simultaneamente à Embrafilme, em 1969, com o filme Os paqueras, de Reginaldo Faria (ABREU, 1996, p. 76-77). Diante de tanta repressão, a sexualidade provocada e discutida por aquela geração acabou encontrando sua linha de fuga por meio das telas do cinema. O grande sucesso de público foi a resposta a um diálogo que já não podia mais ser contornado.

A pornochanchada criou de certo modo um estigma sobre o cinema brasileiro, identificado pela nudez e pelo erotismo. Tendo como polo de produção a chamada Boca do Lixo, no centro de São Paulo, seu sucesso de público influenciou diretores do cinema autoral, como Ana Carolina e Arnaldo Jabor (SILVA, 2010, p. 136). Mesmo a partir dos anos 1980, quando o gênero cinematográfico perdeu força e passou a ser mostrado apenas na "sala especial" da televisão (ABREU, 1996), os filmes que vieram depois ainda traziam como marca a nudez feminina, muitas vezes injustificada e aleatória. Entre as películas dos anos 1970 não era de se estranhar enredos que explorassem personagens masculinos em cenas eróticas com mais de uma mulher ou a rotatividade de parceiras sexuais para um só homem. No cinema aprovado por um regime militar masculinizado, demonstrações de virilidade tinham seu valor.

\section{Os homens que eu tive}

No Jornal do Brasil, em agosto de 1973, a coluna do crítico de cinema Ely Azeredo anunciava uma novidade na cena fílmica, ou o que hoje podemos considerar um acontecimento histórico: Tereza Trautman, uma diretora estreante no cinema brasileiro, exibia desde o mês anterior seu primeiro longametragem - Os homens que eu tive. 
3. Entrevista de Tereza Trautman a Ana Maria Veiga, em 10 de maio de 2010, no Rio de Janeiro.

4. Uma visão mais aprofundada sobre a atriz Leila Diniz e sua personalidade "solar" pode ser encontrada em Silva, 2010, p. 79-99.

5. A expressão dormir com alguém é usada no filme em substituição a fazer amor. O termo dormir, que depois foi substituído por transar, significava ter uma relação sexual independente do envolvimento amoroso, o que estava de acordo com a proposta do filme de

Tereza Trautman.
O filme estreou no Rio de Janeiro em junho de 1973 no cinema Roxy, com seus 1800 lugares tomados. Durante dois meses as sessões continuaram lotadas, tendo estreado também em Belo Horizonte, o que sinalizava um provável sucesso de bilheteria. A vez de São Paulo estava marcada para a Semana da Pátria (setembro) de 1973, quando acabou sendo interditado 3 .

No centro da tela estava Pity, interpretada pela atriz Darlene Glória. O papel era originalmente destinado a Leila Diniz ${ }^{4}$ - atriz que inspirou a criação da personagem e que gerava polêmica por suas atitudes liberais. Leila morreu em um acidente aéreo antes de voltar ao Brasil para iniciar as filmagens. A polêmica em torno de sua personalidade continuaria viva, dessa vez na representação da personagem Pity.

O filme começa com uma cena rotineira entre o casal Pity e Dôde, no café da manhã. Ele lê o jornal, já de gravata, enquanto ela, vestida com uma bata leve, come lentamente, ao lado de um grande aparelho de telefone que ocupa parte da mesa. O telefone toca enquanto Dôde se levanta e veste o paletó para sair. É Peter, que convida Pity para ajudá-lo na montagem de um filme. Na despedida do marido, Pity avisa que não vai dormir com ele naquela noite. Tem um encontro com Sílvio e pode ser que ele vá dormir com ela ${ }^{5}$ em casa (no quarto ao lado). Mas Pity não volta do encontro de trabalho antes das duas da manhã e deixa os dois em casa, esperando por ela. O detalhe do chaveiro rodando nas mãos de Sílvio sinaliza que algo não vai bem.

A cena seguinte acontece em uma locação externa, em plena praia de Ipanema. Pity, Dôde e Sílvio mostram seus corpos bronzeados, espalhados sobre o calor da areia, num lindo dia de sol. Os homens estão calados. Pity informa que ficou trabalhando com Peter, por isso chegou tarde. Reclama que o amante está ficando mais ciumento do que o marido. O clima melhora quando o casal convida Sílvio para morar em seu apartamento. O sobe som de uma trilha estilo bossa nova mostra a animação do triângulo.

A cena é cortada para o interior do quarto de Pity; dessa vez a banda sonora traz a voz de Caetano Veloso, que acabava de voltar do exílio, cantando You don't know me. A batida sensual da música 
acompanha o enquadramento de um grande espelho, na frente do qual Pity entra em cena, os seios nus, que em seguida são cobertos por uma bata sensual. Ela arruma o quarto do amante. Naquela noite, faz sexo com Dôde, mas puxa Sílvio para a cama de manhã, depois que o marido sai. Os lençóis cobrem o encontro dos corpos, sob a luz difusa que entra pela janela e é filtrada pela cortina. Os corpos dos homens são mostrados de maneira sensual, em suas cuecas.

Os primeiros minutos do filme não dão folga ao público espectador, que é pego de surpresa pela naturalidade e a liberdade da personagem. Não é difícil imaginar o impacto desse filme - que (não) mostra o sexo praticado por uma mulher, livre de tabus e regras morais - sobre a censura e a ideologia militar vigente, já que o projeto de governo estava voltado para a normatização da camada média brasileira, com base em regras de conduta que acabavam submetendo as mulheres. A prova de uma ordem do gênero, que se queria preservar nos pré-requisitos da censura, estava no apoio às pornochanchadas, que podiam ser exibidas dentro de sua classificação etária.

O clima da narrativa muda quando Pity e Peter, o cineasta, se apaixonam. O fato é anunciado na narrativa, em termos estéticos, pelo filtro azulado que a diretora decidiu colocar na lente da câmera para representar a decepção de Dôde e Sílvio ao se verem em segundo plano na cena em que Pity passa um bronzeador nos ombros de Peter, o intruso, convidado por ela para relaxar com os três no apartamento de cobertura, com vista para o mar. Ao expandir seus afetos para outro homem, além do amante já permitido, Pity acaba provocando ciúmes não só em Dôde, mas também em Sílvio. O marido vai se consolar nos braços de Alessandra, sua amante. Depois manda Pity embora de casa. No apartamento da amiga Bia, ela decide dar um tempo dos três homens. Duas semanas depois, o marido a procura e a harmonia é retomada. Dôde não quer o desquite, aceita a aproximação entre Pity e Peter. Ele mesmo continua com sua outra namorada.

Mas Pity e Bia decidem morar em um casarão compartilhado por jovens hippies, que escutam música, namoram e trocam de 
parceiros, aproveitam no quintal os dias ensolarados. A mise-en-scène mostra um grupo tocando violão e cantando uma canção no estilo Os Mutantes, enquanto outras pessoas se divertem namorando, pintando ou brincando com cachorros. Eles se preparam para viajar por toda a América do Sul. Comportamentos libertários podiam ser associados ao movimento hippie, mas também à inspiração socialista de Che Guevara e da Revolução Cubana.

Neste contexto, da movimentação no casarão, acontece a cena mais erotizada do filme, em que Pity faz sexo com Vítor, que acabava de chegar à casa, procurando por outra pessoa, e que a encontra chateada. O carinho das mãos no cabelo e no pescoço acaba seduzindo Pity e aos poucos se expande para uma relação sexual. Depois do orgasmo, Vítor pergunta: "Qual é o seu nome?"

Em outra cena, Pity e a amiga Bia aparecem abraçadas, nuas sob os lençóis, fumando um cigarro e conversando, deixando evidente o relacionamento sexual lésbico, provavelmente aberto e fugaz. Pity oferece o novo namorado, Lúcio, para transar com a amiga: "Ele é tão carinhoso, você vai adorar!” A trilha sonora complementa o quadro: "Pra se fazer a cama, precisa de dois..."

Quando todos enfim partem em viagem, incluindo Lúcio e Bia, Pity fica sozinha com Torres, um artista plástico que é o dono da casa, com quem passa a ter um relacionamento aparentemente mais estável. Dôde aparece para visitá-los. A cena final acontece na rua, possivelmente em frente ao casarão, quando o marido se despede. Ela sugere a formação de um novo triângulo, agora com a entrada em cena de um bebê que Pity espera, sem revelar a paternidade. Fica a sugestão de que o filho pode ser criado pelos três, mas Dôde, como marido, quer dar seu nome à criança. Depois de tudo acertado, eles vêm caminhando, conversando, sorrindo, Pity no meio, e passam pela câmera fixa, até saírem de quadro.

Resumido o enredo, trazemos para a análise as palavras de um dos pareceres do Ministério da Justiça, Departamento de Polícia Federal, Divisão de Censura de Diversões Públicas sobre o filme, no momento de seu lançamento: 
6. Documento da Censura em PDF. Disponível em: <www. memoriacinebr.com.br>.

\footnotetext{
7. Entrevista de Tereza Trautman a Ana Maria Veiga, em 10 de maio de 2010, no Rio de Janeiro.
}

Título: Os homens que eu tive. Classificação etária: 18 anos. Cortes: sim. Vedada a exploração comercial: não. Cenas: levianas, da alcova. Linguagem: vulgar e algumas palavras de baixo calão. Tema: social, infidelidade conjugal. Personagem [sic]: vulgares e levianas. Mensagem: negativa.

Enredo: Pity, mulher leviana, deixa o marido, que também mantinha relações extraconjugais, e prossegue sua vida com vários homens. No final, ela engravida de um dos companheiros, fica muito feliz e comunica o acontecimento ao marido, pedindo o desquite.

Cortes: No trailer - palavrão porrada. Segundo rolo do filme - palavrão filho da puta.

Conclusão: trata-se de película com conteúdo amoral, baseado no adultério. Opinamos pela liberação para maiores de 18 anos, com os cortes acima mencionados. Brasília, 01 de junho de $1973^{6}$.

O parecer 3612/73, mencionado acima, foi assinado por duas mulheres e um homem que avalizaram a exibição do filme a partir de junho de 1973. Pela quase ausência de cortes sugeridos, percebemos que a película de Trautman não deve ter causado tanto incômodo aos censores, ao menos no início. $\mathrm{O}$ que parece ter chamado sua atenção, como confirmaremos mais adiante, é o comportamento de uma mulher casada e liberada. Afinal, como uma protagonista poderia desvendar ao público espectador sua intimidade e liberdade de escolha sexual com tanta naturalidade? Como uma jovem ousava ser a primeira diretora do cinema brasileiro no período ditatorial e ainda trazer à tona esse tipo de temática? E se as mulheres das boas famílias resolvessem pensar assim também? O mal teria que ser cortado pela raiz, com a tesoura moral da censura. Isso aconteceria pouco tempo depois.

"A ditadura tinha me proibido de discutir a realidade social do país, mas havia uma questão privada, que era social, que era a condição feminina, que eu ia discutir" ". Ou seja, Tereza queria, mas não podia questionar a política. Aderiu, então, de certo modo ao slogan do feminismo "o pessoal é político", trazendo um problema de gênero para as telas e para os balcões do departamento de 
8. "Fantasias de Tereza sem traumas", de 18 ago. 1980, p. 19.

9. "Os homens que eu tive, liberado sete anos depois", de 12 ago. 1980 , p. 20.

10. "Os homens que eu tive, uma derrota da censura", de 11 ago. 1980, p. 17; "Os homens que eu tive,

Filmes novos", de 18 ago.1980, p.

19; "Simpático, simples, direto. E levemente ingênuo", de 18 ago. 1980.

11. Eu a entrevistei em maio de 2010 no Rio de Janeiro e pude sentir a mágoa acumulada naqueles anos.

12. Entrevista de Tereza Trautman a Ana Maria Veiga, em 10 de maio de 2010, no Rio de Janeiro. censura. Seu posicionamento não ficou sem resposta. Dois meses depois da estreia e do sucesso inicial, Os homens que eu tive foi censurado e permaneceu na geladeira, assim como sua realizadora, por longos anos.

Pesquisas em jornais como A Folha de São Paulo ${ }^{8}$ O Estado de São Paulo ${ }^{9}$ Jornal da Tarde ${ }^{10}$ saídos em agosto de 1980, e também nos documentos da censura, mostraram que o filme foi liberado naquele ano, apesar de sua diretora ter afirmado em entrevista que foram dez anos de interdição. Isso demonstra que o tempo psicológico de interdição pode ter sido maior do que o tempo histórico para a cineasta, que passou anos batendo de porta em porta em busca da liberação. Para nós, fica o alerta das inúmeras possibilidades abertas pelos relatos de memória, que não devem ser tomados como histórias de vida, mas como interpretações subjetivas dos fatos.

E por falar em memória, o rosto de Tereza se fechou, colérico, ao mencionar ainda recentemente a censura ao filme ${ }^{11}$. Depois de muitas visitas aos órgãos do governo, finalmente ela soube que a ordem de veto tinha vindo lá de cima, do alto escalão militar ${ }^{12}$. A interdição foi feita diretamente pelo general Antônio Bandeira, então diretor geral do Departamento de Polícia Federal. A cineasta contou que, de acordo com o que lhe diziam - antes da estreia em São Paulo, depois de um mês e meio de sucesso no Rio de Janeiro e de duas semanas em cartaz em Belo Horizonte -, o filme teria sido denunciado por uma mulher não identificada, por ser um atentado contra a imagem da mulher brasileira e contra a família. De acordo com Tereza, não havia motivo justificável para a interdição, pois a película não trazia nenhuma cena explícita. Mesmo assim, foi tomada como subversiva.

Seu nome entrou para o índex proibitivo da censura ditatorial e cada projeto que apresentava ou do qual participava já era negativamente carimbado e vetado, não importando seu conteúdo. Em 1975 foi a vez de um segmento do filme As deliciosas traições do amor, baseado em contos do Marquês de Sade. Dividindo espaço com adaptações de outros diretores, entre eles Domingos Oliveira, Tereza relata que teve sua parte totalmente picotada 
13. Trata-se do segmento intitulado "Dois é bom... quatro é melhor"

14. Peça musical escrita e composta para o teatro por Chico Buarque de Holanda em 1977, também gravada em disco.

15. Entrevista de Tereza Trautman a Ana Maria Veiga, em 10 de maio de 2010, no Rio de Janeiro. pela censura' ${ }^{13}$. Depois, em 1976, iniciou a produção de um filme sobre D. Hélder Câmara, em contrato com a TV francesa Antena 2, que foi cancelado sob a ameaça de negação de visto para o diretor da empresa que a havia contratado. Em 1978 pediu apoio da Embrafilme para rodar Os saltimbancos ${ }^{14}$. Passado o entusiasmo inicial, encontrou seu entrave nas palavras do diretor geral do órgão na época, Roberto Farias, que ela reproduziu: “Tereza, você já fez um filme interditado. Chico Buarque, um sujeito interditado... Eu não posso financiar, botar dinheiro da Embrafilme num filme que vai ter problemas com a censura"15 . Sempre a censura...

Ao analisarmos o mais polêmico filme dessa autora, nos deparamos também com o debate sobre as reivindicações feministas que apareciam com força naqueles anos. Por um lado, o crítico Ely Azeredo tentava proteger Tereza desse estigma:

Primeira mulher a realizar um longa-metragem no Brasil desde a década de 1950, Tereza Trautman poderá reivindicar um lugar na história do cinema brasileiro, no mínimo como a primeira realizadora a filmar entre nós com um ponto de vista nitidamente feminino. Classificar Os homens que eu tive de feminista me parece apressado e, a julgar pelas distorções sectárias sempre presentes nos movimentos feministas, uma atitude talvez injusta. Um 'cinema feminino' está longe do pensamento da autora (AZEREDO, 2009, p. 208).

Este argumento, elaborado no calor do momento, mostrava a ausência de um conhecimento aprofundado do que representou o movimento feminista, além do preconceito contra as feministas, vistas então, e muitas vezes até hoje, como sectárias. Mas o curioso contraponto é que, em entrevista, Tereza Trautman falou da proximidade com as ideias feministas e do contato que teve com alguns grupos, chegando a participar de reuniões e compartilhar ideais. Ela relembrou: "Quando eu escrevi Os homens que eu tive, eu falei: Ah é? Essa coisa de 'as mulheres que eu tenho'... Eu disse: Não! As mulheres também! Então, 'Os homens que eu tive”".

Sérgio Augusto, colunista da revista Veja, viu em Os homens que eu tive uma "versão corriqueira de As duas faces da felicidade, 
de Agnès Varda” (Veja, 1 ago. 1973). Azeredo também comparava os dois filmes. "Sem dúvida Varda comunica um prisma feminino, mas o mais importante em As duas faces da felicidade é uma visão de liberdade existencial [...]" (AZEREDO, 2009, p. 208). Ou seja, a perspectiva feminista perdia importância diante de questões existenciais (entenda-se não feministas).

A variação importante entre as duas películas é que Varda colocava um homem como protagonista. Cada mulher era para ele apenas "mais uma rosa em meu jardim”. A leveza e a naturalidade com que isso foi mostrado levou a cineasta a sofrer duras críticas, devido ao otimismo com que tratava a questão da desigualdade, por valorizar a natureza feminina e por não historicizar as mulheres (JOHNSTON, 2000[1973], p. 32).

No caso de Os homens que eu tive, a protagonista levava a um repensar de papéis dentro de uma sociedade tradicionalmente marcada pela submissão das mulheres e por uma criação direcionada para que, acima de tudo, elas zelassem por seu casamento, aceitando as escapadas do marido, um comportamento considerado inerente ao sexo masculino. Pity, ao se relacionar com outro homem, além daquele permitido pelo marido, acaba provocando uma crise conjugal. Sem reconhecer ou aceitar limites, ela sai de casa e dá continuação a suas aventuras.

Alberto da Silva observa que a existência da personagem Pity só é possível no recorte espacial em que acontece: a Zona Sul do Rio de Janeiro, onde algumas mulheres da classe média podiam experimentar certa liberação sexual nos anos 1970. Para Silva, a única janela que o filme de Trautman abre para a vida comum da maioria das mulheres brasileiras é o encontro de Pity com sua irmã, mãe de três filhos e que acabara de se separar. Depois desse encontro, a protagonista começa a pensar em engravidar (SILVA, 2010, p. 109-110). Observamos que, como contraponto de Pity, a irmã é submissa ao marido e abriu mão de ter um trabalho para viver apenas dentro do casamento e da família. Ela é interpretada pela própria cineasta, que se coloca em cena como a coadjuvante que faz falar ainda mais alto a subjetividade da protagonista. 
16. Entrevista de Tereza Trautman a Ana Maria Veiga, em 10 de maio de 2010, no Rio de Janeiro.
17. "Ironiquement, si le titre Todas as mulheres do mundo n'avait pas causé de malaise chez les censeurs en 1966, le film de Teresa Trautman en causa en mettant les femmes sur un pied d'égalité inacceptable pour le pouvoir phallocentrique de la dictature militaire des années 1970, au moment même où triomphait la production cinématographique érotique (pornochanchadas)". Tradução nossa.
Antoine de Baecque analisa o corpo do/a cineasta "como lugar mesmo do cinema" e observa que a prática do cinema "autocorporal" fez parte do chamado "cinema moderno", como "[... um desejo de encarar a principal invenção teórica dos críticos que formam a Nouvelle Vague, a política dos autores", além de "moldar uma singular aparência de si mesmos" (BAECQUE, 2008, p. 501)

Pity conquistava seu espaço num momento em que o movimento hippie e a liberação sexual que o perpassava cruzavam fronteiras nacionais e ameaçavam bater à porta dos regimes militares latinoamericanos. Sobre a protagonista, a diretora informa: "Ela não sente nenhuma culpa. É o que ela tem vontade de fazer e é o que ela vai fazer. Não é uma carga"16 .

Silva sinaliza o contraste entre o filme Todas as mulheres do mundo, de Domingos Oliveira - também inspirado em Leila Diniz e estrelado por ela -, e o de Tereza Trautman, como narrativa biográfica de uma mesma atriz, símbolo da liberação da nova mulher de Ipanema e da Zona Sul carioca:

\begin{abstract}
Ironicamente, se o título Todas as mulheres do mundo não causou mal estar entre os censores em 1966, o filme de Tereza Trautman o causa ao colocar as mulheres em um pé de igualdade inaceitável pelo poder falocêntrico da ditadura militar dos anos 1970, momento em que triunfava a produção cinematográfica erótica (pornochanchadas) ${ }^{17}$ (SILVA, 2010, p. 109).
\end{abstract}

Apesar de lançado antes dos chamados anos de chumbo, o que já explica parte da pressão sofrida por Trautman, o filme de Oliveira tratava de aventuras amorosas em nada questionadas, por serem vividas por um homem.

Ao contrário dos exemplos de outras realizadoras brasileiras, como Ana Carolina e Helena Solberg (cf. VEIGA, 2013), Tereza Trautman, enquanto a ditadura durou, foi uma cineasta sem películas, frustrada em seu talento e em seus sonhos. "Minha carreira teria sido outra, minha vida teria sido outra, tudo teria 
18. Entrevista de Tereza Trautman a Ana Maria Veiga, em 10 de maio de 2010, no Rio de Janeiro.

19. "Simpático, simples, direto. E levemente ingênuo”. Jornal da Tarde, 18 ago. 1980.

20. Já que não consta dos vinte e oito documentos da censura ao filme qualquer registro de um pedido formal de interdição em Belo Horizonte, podemos pensar na hipótese de tal solicitação ter sido feita pessoalmente ao general

Antônio Bandeira por alguma pessoa conhecida dele ou mesmo por alguém da sua família. Este fato pode ser um indicador da arbitrariedade como elemento central do aparelho repressor brasileiro nos anos de ditadura.

21. Carta da empresa Produções Cinematográficas Herbert Richers S.A. ao Ministério da Justiça. Disponível em: <www. memoriacinebr.com.br/ pdfsNovos/0890473C01104.pdf>. Acesso em 19 jan. 2013. sido diferente"18, desabafa. Liberado para exibição em 1980, Os homens que eu tive não causou o mesmo impacto sobre o público como havia acontecido sete anos antes, como podemos perceber com a crítica mais dura ao filme ${ }^{19}$, que o tomava como ingênuo sem contextualizá-lo dentro de uma história de repressão à busca de igualdade das mulheres nos anos 1970 e mesmo dentro das limitações dos recursos cinematográficos da época.

Mas, em que medida a interdição ao filme teria sido parte de um projeto de intelligentsia militar? Ou seria ela movida por decisões meramente arbitrárias? ${ }^{20}$ Já que em momento algum a diretora questionou em seu filme o regime político e seus efeitos, apenas relações de gênero envoltas em valores morais, podemos perceber a força dos projetos autoritários (não apenas no Brasil, é claro), que tinham como meta a reação à subversão e a afirmação de sua ideologia política, que compreendia esses valores.

Em carta ao ministro da justiça, Armando Falcão, em 12 de junho de 1974, a produtora Herbert Richers, responsável pelo filme e há um ano pedindo sua liberação, evocava a exibição no Brasil de filmes como Jules e Jim (1962), de François Truffaut e Cesar e Rosalie (1973), de Claude Sautet, que traziam temáticas semelhantes à de Os homens que eu tive, mostrando mulheres envolvidas com mais de um homem. Possivelmente essa subversão de costumes era tolerada como estrangeirismo, mantendo intacta a moral das mulheres brasileiras casadas. A produtora argumentava que: "Paralelamente às chanchadas pornográficas que importamos e que são também produzidas no Brasil há alguns anos, existe o cinema erótico sério [...]" e que o filme de Tereza Trautman seria um de seus representantes, assim como Toda nudez será castigada, de Arnaldo Jabor, também interditado em 1972, mas liberado com cortes no ano seguinte ${ }^{21}$.

De acordo com Nuno Cesar Abreu, o filme de Jabor foi um dos mais destacados do chamado cinema erótico. Para este autor, a moral era o veículo do controle social, como expressão organizada dos bons costumes, reprimindo e ajustando os indivíduos (ABREU, 1996, p. 74). Foi ela a justificativa evocada na interdição de ambos os filmes aqui mencionados. 
O argumento da produtora Herbert Richers de que Os homens que eu tive seria representante do "cinema erótico sério" nos remete à distinção entre filme erótico (soft core) e filme pornográfico (hard core), entre o sugerido e o explícito (ABREU, 1996).

O citado filme de Jabor, adaptado da obra de Nelson Rodrigues, foi visto pelos censores como carregado de erotismo e cenas de nudez, com sentido negativo para a sociedade brasileira. Mesmo tendo sido indicado para cortes na estreia e com classificação etária de 18 anos, também foi interditado, mas, ao contrário de Os homens que eu tive, Toda nudez será castigada foi liberado um ano depois.

Enquanto Tereza Trautman e a produtora ainda brigavam pela autorização de exibição, em 1977 os documentos da censura mostram o filme de Jabor já pedindo autorização para ser exibido na televisão. O motivo de tal diferença pode ser presumido ao analisarmos os discursos dos seus pareceres nos processos de censura.

22. Disponível em: <www. memoriacinebr.com.br>.
Parecer 4645/73. Título: Toda nudez será castigada. Classificação etária: não liberação.

Cenas: de desajustamento familiar, conflitos, relações de sexo, de exibicionismo erótico, de fuga, de suicídio. Linguagem: vulgar, de baixo calão, sórdida. Tema: psicossocial. Personagens: sadomasoquistas, desajustados, angustiados. Mensagem: negativa.

Enredo: O sexo e o erotismo são recursos engendrados para desfazer a obsessão do viúvo pela ex-esposa, e, também, como instrumento de vingança do filho contra o pai, que com uma prostituta formam um triângulo amoroso. São marcantes as cenas de exibicionismo erótico, indução sexual, curra, tendo como desfecho o suicídio da prostituta de um lado, e do outro, a opção do filho pelo homossexualismo.

Conclusões: [...] Embora apresente nível técnico que o tenha credenciado a mais de um prêmio como arte, o seu conteúdo, entretanto, é negativo, sob o ponto de vista das instituições morais e sociais. Por conseguinte, $[\ldots]$ sugerimos sua não liberação.

Brasília, 10 de julho de 1973. Maria Bemvinda Bezerra ${ }^{22}$ 
23. Documento anexo ao certificado de censura do filme, expedido pelo Ministério da Justiça, Departamento de Polícia Federal, Divisão de Censura de

Diversões Publicas e assinado por Rogério Nunes e Deusdeth

Burlamaqui em 21.12.1972.

24. Despacho do gabinete do Diretor Geral do Departamento de Polícia Federal, Antônio Bandeira. 08 ago. 1973. Disponível em www. memoriacinebr.com.br. Acesso em 19 jan. 2012.

25. Dados da Agência Nacional do Cinema. Disponíveis em: $<$ http://www.ancine.gov.br/media/ SAM/2011/filmes/por_ano_1.pdf>. Acesso em 20 jan. 2012
Apesar de dois pareceres negativos, o mesmo general, Antônio Bandeira, decidiu liberar em 8 de agosto de 1973 a exibição do filme de Jabor, exigindo os devidos cortes já sugeridos na saída do filme em 1972: cortar a palavra suruba, o gesto que Geni faz batendo com a mão aberta sobre a outra fechada, a fala de Geni "Perto de você eu fico toda molhadinha", a fala de Herculano "Eu vou deflorar você", a cena que apresenta o ambiente policial como "antro de depravação e irresponsabilidade"23. Além disso, o documento do general Bandeira exigia o corte de boa parte das cenas de Geni no bordel com o "busto desnudo", uma cena em que o casal se acaricia sexualmente no sofá, outra em que Geni é mostrada com "os dois seios de fora" tentando seduzir Serginho. O general também proíbe a cena em que o jovem foge com o preso boliviano que o estupra na cadeia, mandando cortar inclusive parte final da banda sonora quando Geni diz: “Teu filho fugiu, com um ladrão boliviano". Assim o homossexualimo (termo que dá significado patológico à sexualidade) também seria eliminado do filme ${ }^{24}$. Pelo que notamos na descrição feita do enredo, Toda nudez será castigada poderia ser considerado bem mais ousado e explícito em termos de cenas picantes do que Os homens que eu tive, o que justificaria sua interdição. Ao contrário disso, foi liberado simultaneamente ao engavetamento do outro, e pelo mesmo oficial.

Em 1973, Toda nudez será castigada, terceiro longa-metragem de Arnaldo Jabor, ganhou o Urso de Prata em Berlim e foi o vencedor do Festival de Cinema de Gramado, onde Darlene Glória também levou o Kikito de melhor atriz. Depois da liberação, com cortes, sua bilheteria registrada pela Ancine foi de 1.737.151 espectadores ${ }^{25}$.

Podemos inferir que o cinema-arte de Jabor, adaptando Nelson Rodrigues, tenha convencido os censores a respeito de sua qualidade artística, confirmada pela premiação que acumulou.

Quanto ao filme de Trautman, uma vez censurado e com suas cópias recolhidas, passou a ter um tratamento bastante rígido, impregnado de uma carga moral ainda mais evidente, como percebemos nos pareceres de 1975, em resposta a um novo pedido de liberação por parte da produtora Herbert Richers, com o filme já cortado nos dois palavrões e com título alterado para Os homens e eu, por sugestão da própria censura. 
Parecer 4680/75. Título: Os homens e eu. Classificação etária: não liberação.

Enredo: Mulher casada troca a segurança do lar e do marido por vida libertina, prostituída até o dia em que resolve engravidar-se [sic] do último homem que tivera, quando reencontra com o marido, que sempre lhe dera cobertura para todos os atos de prostituição e pouca vergonha.

Conclusão: Filme amoral, pornográfico em sua mensagem, debochado, cínico, obsceno que tenta com enredo mal feito justificar a vida irregular de mulher prostituída. É um libelo contra a instituição do casamento, considerando como tal todas as investidas irregradas da insaciável mulher.

É uma afronta à moral e aos bons costumes, em que pese os interessados terem subtraído os poucos palavrões existentes.

É o mesmo filme que já foi objeto de exame e posterior interdição (Os homens que eu tive), tendo sido, apenas, mudado o nome. A bem da moral, bons costumes, à [sic] instituição do casamento, à [sic] sociedade, das pessoas normais e de bem, somos pela NÃO LIBERAÇÃO [grifo original].

Brasília, 23 de maio de 1975. Joel Ferraz - Técnico Censor.

Os limites de um julgamento técnico perdem lugar para a força e o peso do julgamento moral, quase passional. O enredo do filme, apresentado pelo censor, é bastante diferente daquele descrito no primeiro parecer, que foi elaborado na época da estreia. De acordo com este último (parecer 4680/75), a mulher que tem mais de um parceiro leva "uma vida libertina, prostituída". O filme, além de amoral, é "pornográfico em sua mensagem”, ou seja, fica claro que não o é em suas imagens. A mensagem gera o problema, mostrando "as investidas irregradas da insaciável mulher", colocando-a num lugar culturalmente aceitável apenas para homens. $O$ apelo veemente à "NÃO LIBERAÇÃO", com caixa alta, fecha o texto do parecer, no qual o censor afirma por duas vezes querer proteger a moral, os bons costumes, o casamento, a sociedade e as pessoas “normais e de bem". Ou seja, Pity não era, para ele, nem normal nem de bem, mas uma anomalia, do mal. 
26. No capítulo "Corpos dóceis", de Vigiar e Punir, Michel Foucault argumenta sobre o estabelecimento do normal como princípio de coerção. Os desvios deveriam ser reduzidos, por meio de penalidades

aplicadas ao "campo indefinido do não-conforme”, do anormal.

O "poder da Norma” faria parte das leis da sociedade moderna (FOUCAULT, 2002 [1975], p. 148154). Podemos associá-lo às práticas dos regimes militares sul-americanos.
O apelo ao adjetivo normais para o sujeito pessoas aponta para o sentido foucaultiano de "normalização"26, explorado por Judith Butler, por vezes traduzido como "normatização". Este sentido está evidente no discurso do censor, já que o filme de Tereza Trautman trazia uma protagonista que fugia à normalidade social, que compreendia a mulher submissa, dentro do casamento. Para Butler, “[...] as práticas reguladoras que governam o gênero também governam as noções culturalmente inteligíveis de identidade”, ou seja, a coerência da pessoa é uma norma de inteligibilidade socialmente instituída e mantida (BUTLER, 2003, p. 38).

Pity teria cruzado os limites do gênero com um comportamento quase masculino. Suas "práticas perturbadoras" questionam o que Butler chamou "heterossexualidade compulsória" (2003, p. 39). E mais, no caso do filme analisado, são uma afronta ao controle da sociedade pelas regras do governo militar. $\mathrm{O}$ regime exigia respeito a uma hierarquia hetero-normativa, onde a iniciativa nas relações via de regra é tomada pelos homens, detentores do controle da relação e da família. O sexo, para Pity, não estava ligado à reprodução, tampouco restrito ao casamento ou à hetero-normatividade. Era um prazer e não tinha motivos para ser reprimido. Fugindo à norma que deveria ser reiterada, e marcada assim como antagonista das pessoas de bem, essa personagem representava um perigo para a sociedade idealizada. É o que podemos observar na retomada dos argumentos a propósito do filme, já com o título Os homens e eu, em 1975. O adjetivo obsceno indicava que estava colocado em cena aquilo que deveria permanecer escondido. $\mathrm{O}$ mal que a película representava deveria ser extirpado, ao mesmo tempo que o governo sustentava a produção de filmes eróticos que enfatizavam a repetição dos papéis de gênero pré-estabelecidos.

Nas pornochanchadas, mulheres sexualmente ativas estavam em cena para serem consumidas, não para escolher ou consumir, como a protagonista Pity. Adaptando as palavras de Nuno Cesar Abreu, sugiro que Tereza Trautman tenha feminilizado de algum modo as representações "ao situar a mulher como sujeito e como produtora de material pornográfico" (ABREU, 1996, p. 36), aqui, no caso, erótico sério. 
27. Cf. www.memoriacinebr.com.br.
De volta ao parecer 4680/75, é interessante também observarmos no início da conclusão a crítica ao "enredo mal feito" do filme, o que mostrava sutilmente um outro lado da profissão do censor, que acabava tomando (vaidosamente) a si mesmo como crítico de cinema, apto a dar opiniões estéticas, além de decidir sobre a pertinência moral de cada filme. Ou seja, sua profissão, ligada ao cinema, também teria certo vínculo artístico.

Um segundo documento (4681/75), assinado dessa vez por José M. A. Tolentino em 23 de maio de 1975, afirma que o enredo do filme faz "dessa agressão aos nossos princípios de moral e bons costumes uma coisa simplesmente normal”. Mais uma vez a crítica da censura ecoa: "isso não é normal". Indo no mesmo sentido dos outros dois, o último parecer (4682/75) não deixa qualquer dúvida: "O filme é totalmente AMORAL, contrariando os princípios que norteiam os critérios censórios vigentes. Propõe constantemente a destruição da instituição do Casamento. Estimula a prática do sexo livre e desmoraliza a figura da mulher casada" 27.

O abjeto - no caso a representação da mulher casada que foge aos padrões sociais - designa “as zonas inóspitas e inabitáveis da vida social", que são densamente povoadas por aqueles que não gozam do estatuto de sujeito (BUTLER, 2001, p. 155-156). E que por isso devem ser combatidos, assim como a representação de Pity.

Curiosamente, é a mesma atriz, Darlene Glória, que protagoniza os filmes de Jabor e de Trautman, sendo que em Toda nudez será castigada a personagem encontra-se no lugar adequado para uma prostituta: um bordel. Talvez por isso o filme possa ter sido liberado, pois não rompia com as convenções sociais vigentes. A prostituta, vista como mulher de vida fácil, poderia ser traiçoeira e vulgar, sem maiores problemas para sua imagem já assimilada. Por outro lado, no enredo de Os homens que eu tive Darlene Glória fazia o papel de uma mulher casada, de classe média, que mantinha relações com outros homens. Apesar de não receber qualquer dinheiro por isso, Pity foi denominada prostituta pelos censores. Muito pior do que a primeira, ficava subentendido que ela fazia o que fazia porque realmente gostava disso, no sentido pejorativo. A mácula na imagem da mulher casada era mais do que suficiente para uma sentença de interdição quase perpétua. 
28. Aqui mais uma coincidência entre Os homens que eu tive e Toda nudez será castigada - os dois filmes foram distribuídos pela Ipanema Filmes.
Quanto à atriz, ela também sofria as consequências de suas personagens, sendo muitas vezes identificada ou confundida com elas, como percebemos em uma crítica da estreia do filme:

\begin{abstract}
“OS HOMENS QUE EU TIVE” - Se em “Toda nudez será castigada” Darlene Glória sofria na mão dos homens, a vingança veio rápida, pois em "Os homens que eu tive" estes é que sofrem sob a ação de seus caprichos. E olhe que os homens são uns "pães”, como Gracindo Júnior, Arduíno Colassanti, Milton Moraes, Gabriel Arcanjo e Roberto Bonfim. É certo que o fato do diretor ser uma mulher (Tereza Trautman, 22 anos) ajuda esta situação, mas Darlene vai mesmo à forra, pois além dos homens, tem oportunidade de transar com Ítala Nandi e Annick Malvil numa história profundamente humana e sincera, de autoria da própria diretora. "Os homens que eu tive", numa apresentação da Ipanema Filmes ${ }^{28}$, estréia no próximo dia 3 no circuito do cine Ipiranga (Folha de São Paulo, 23.08.1973).
\end{abstract}

Isso significa que a crítica (provavelmente uma mulher, já que chama os atores de pães - linguagem coloquial na época para se falar sobre homens bonitos) recomendava bem o filme e chamava o público para ir às salas de cinema ver a atriz Darlene Glória transar com atores bonitos e ainda com as atrizes Ítala Nandi e Annick Malvil. Infiro que, se esse tipo de mentalidade podia estar impresso nas páginas de um grande jornal, ele também estaria presente no senso comum de muitos leitores e leitoras. As atrizes seriam menos ou mais respeitáveis de acordo com as personagens que aceitavam interpretar no cinema ou na televisão. Julgamento semelhante poderia ser aplicado a uma diretora que ousasse rodar um filme como Os homens que eu tive.

Depois de 1976, com autorização de exportação, a exibição do filme ocorreu em alguns festivais fora do Brasil, como o de New Orleans (1976), que exibiu filmes brasileiros tirados de cartaz pela ditadura militar. Isso nos mostra que o espaço para o cinema mais questionador dos costumes e da política estava fora do país. 
29. Entrevista de Tereza Trautman a Ana Maria Veiga, em 10 de maio de 2010, no Rio de Janeiro
Trautman marcou posição no diálogo sobre a situação hierárquica inferior das mulheres nas sociedades brasileira e latino-americana. Com sua trajetória, podemos refletir sobre a verdadeira lei que esteve em vigor durante os anos da ditadura no Brasil: a lei moral do mais forte, do governo militar e seus valores conservadores, principalmente no que dizia respeito às relações de gênero e ao lugar das mulheres. A imagem da verdadeira brasileira era aquela da mulher de camada média, religiosa, dona de casa, mãe zelosa, esposa compreensiva e disponível para seu marido; a mulher patriota, responsável pela economia, pelo consumo e pela criação dos filhos da nação. Assim como no tratamento aos militantes combativos de esquerda, as mulheres que estivessem fora desse padrão e o desafiassem, também estavam fora do sistema e poderiam ser livremente consumidas.

Podemos concluir que, apesar de ter sido aclamada pela imprensa como a primeira mulher diretora do cinema moderno brasileiro, de acordo com a crítica de Ely Azeredo em agosto de 1973, Tereza Trautman pagou o preço por ter permanecido no país durante a repressão e por ter batido de frente com a ideologia militar. Elogiada por sua competência e criatividade na elaboração de um filme de realização simples e orçamento barato, como Os homens que eu tive, ela talvez tenha sido a grande representante de uma geração: "Cineastas amordaçadas. Talvez seja esse o título que deveria se dar a toda essa geração, essa leva de mulheres"29). Assim define as diretoras que, como ela, tiveram de se submeter aos caprichos da censura ou simplesmente não puderam se expressar. 


\section{Referências}

ABREU, N. C.. O olhar pornô. Campinas: Mercado de Letras, 1996.

AZEREDO, E. Olhar crítico: cinquenta anos de cinema brasileiro. São Paulo: Instituto Moreira Salles, 2009.

BAECQUE, A. de. "O corpo no cinema". In: CORBIN, A.; COURTINE, J.-J.; VIGARELLO, G. História do corpo. V. 3: As mutações do olhar - o século XX. Petrópolis: Vozes, 2008.

BUTLER, J. "Corpos que pesam: sobre os limites discursivos do ‘sexo”". In: LOURO, G. L. (Org.). O corpo educado. Belo Horizonte: Autêntica, 2001.

Problemas de gênero: feminismo e subversão da identidade.

Rio de Janeiro: Civilização Brasileira, 2003.

FOUCAULT, M. Vigiar e punir. Petrópolis: Vozes, 2002.

GIORDANO, V. "Medios masivos, política y vida cotidiana en Brasil. Apuntes para un estudio de la revista Playboy (Brasil), 1975-1985”. Comunicação oral. III Jornadas de Historia, Género y Política en los '70. Buenos Aires - Argentina, set. 2010.

JOHNSTON, C. "Women's cinema as counter-cinema". In: JOHNSTON, C. (Org.). Feminism and film. New York: Oxford University Press, 2000.

MALAFAIA, V. "O cinema e o Estado na terra do sol: a construção de uma política cultural de cinema em tempos de autoritarismo". In: CAPELATO, M. H. et al. História e cinema. São Paulo: Alameda, 2007.

SILVA, A. da. Archaïsmes et modernité: les contradiction des modèles féminins et masculins dans le cinéma brésilien de la dictature. Un regard sur les films d'Ana Carolina et Arnaldo Jabor. Thèse en Histoire, Université Sorbonne - Paris IV, Paris, 2010.

VEIGA, A. M. Cineastas brasileiras em tempos de ditadura: cruzamentos, fugas, especificidades. Tese (Doutorado) Universidade Federal de Santa Catarina, 2013. 